\title{
Organizing Public Good Provision: Lessons from Managerial Accounting
}

\author{
Benito Arruñada and Stephen Hansen ${ }^{*}$
}

This version: October 2014

\begin{abstract}
This paper applies ideas and findings from Managerial Accounting to the problem of public good provision. It first links the problems of traditional bureaucracies with those of “discretionary expense centers”, which are characterized by poor user and supplier incentives as well as overproduction. It then describes alternative hybrid organizations that delegate authority and provide incentives on some dimensions, while maintaining control on others. Finally, it illustrates the ideas with several cross-country case studies on public registries, illustrating that such hybrids may provide a superior, if imperfect, solution to the problems that governments face when lacking sufficient information to directly control the activities of public goods’ providers.
\end{abstract}

Keywords: Public Good Provision, Managerial Accounting

JEL: H40, M48

\footnotetext{
*Pompeu Fabra University and Barcelona GSE. E-mails: benito.arrunada@upf.edu, stephen.hansen@upf.edu. We thank Yannick Perez, Barry Weingast, participants at the EIU Workshop on "Legal Order, The State and Economic Development" and the CUNEF Workshop on "The Economics of Institutions and Organizations", the guest editors Eric Brousseau and Jérôme Sgard, and three anonymous referees for their comments, as well as the support of the Spanish Ministry of the Economy and Competitiveness, through grant ECO2011-29445.
} 


\section{Introduction}

The narrative for justifying government production of goods and services has its roots in external effects. When parties outside a market transaction experience some positive or negative payoff from its execution, even perfectly competitive markets cannot deliver efficient outcomes because the price at which trade occurs no longer reflects all social benefits/costs. So, for example, the reason that governments provide fire services is that any one individual's valuation of purchasing fire services in a market is less than the social value, which would also include the benefit to his neighbors. Other classic examples of services with positive external effects that government generally provides are the courts, the police, and the army.

While the rationale for government provision of public goods is well known, how to organize their production is less well understood. Once the government takes over the provision of a public service, it still must decide how to deliver it. For the most part, governments themselves do not directly deliver any services; they instead tend to delegate delivery to departments within the civil service (or sometimes outside contractors), which themselves must decide how to allocate resources to provide the service. Questions such as how much discretion to allow government departments, and how to motivate their managers and staff, must be answered.

Failure to effectively organize public good provision is common and substantially decreases efficiency. A typical solution is to adopt a command-and-control bureaucratic structure in which providers have little discretion and no incentives, which, we show, can lead to serious problems. At the same time, for the reasons sketched above, relying on the opposite extreme of a pure market with full discretion and powerful price-based incentives is suboptimal in a public-good setting.

The primary goal of this paper is to show that these "corner" solutions are only two possibilities among a range of organizational types that restrict providers' discretion on some dimensions while allowing freedom (with appropriate incentives) on others. In other words, we conceive of public-good provision as consisting of multiple tasks (e.g., 
what price to set or what quality level to provide), some of which can be bureaucratically controlled and some of which can be left in the hands of providers. We will refer to an organization that adopts such a mixture as hybrid.

While this point is often overlooked (or at least not explicitly recognized) in discussions of bureaucratic reform, the Managerial Accounting literature has long observed that divisions within companies have discretion on some dimensions and not on others, and that the degree of decentralization is inseparable from the problem of how to effectively motivate good performance. The second goal of the paper, therefore, is to put forth a framework based on Managerial Accounting principles to think about the tradeoffs among different kinds of organizations. Our aim is not to provide a new theory of public management, but rather to highlight that standard frameworks in the Managerial Accounting literature can be used to analyze the costs and benefits of various forms of public sector organization. More concretely, we identify a variety of organizational types between pure bureaucracy and pure markets that can be used in the public sector, and discuss their typical advantages and disadvantages.

This exercise is valuable because, while the problems associated with traditional bureaucracies are often apparent, how to address them is a source of perennial confusion. A case in point is the National Health Service (NHS) in the UK. By the 1980's observers recognized that the NHS was suffering from inadequate organization. E.g., wages were independent of performance, there was no attempt to measure costs, and the central government decided on all human resource policies. Enthoven (1991) summarized the then prevailing philosophy:

The normal assumption in the public sector-including the NHS-is that the output cannot be defined and measured, so the producers cannot be held accountable for it. So, in a manner typical of the public sector, producers are held accountable for the use of inputs by budgetline items, such as nurses' salaries, building repairs, and disposable services. Then the focus of accountability is not, "Did you produce the greatest output possible with these resources?” but rather, “Did you operate within these budget limits?”

These apparent distortions initiated a period of reform in the NHS that continues to this day. However, the approach of successive UK governments to NHS organizational reform could fairly be described as unfocussed; every few years new and costly 
initiatives are proposed, debated, and put in place, only to be changed again shortly thereafter. While this endless tinkering may in part reflect the political election cycle, the lack of a coherent and unified way to think about public sector organizations is likely a contributing factor. Our paper provides a starting point for this challenge. Since the goal of the paper is ultimately policy-oriented, the third contribution is to illustrate the application of the Managerial Accounting framework to the organization of public goods. Relying on a case study of different registries, we link the advantages and disadvantages of alternative organizational structures predicted by the theory to realworld outcomes, thus demonstrating the challenges and tradeoffs governments have faced in designing effective organizations for the provision of public goods.

\section{Public Good Provision and Managerial Accounting}

In the context of private sector multi-division companies, the Management Accounting literature distinguishes among alternatives according to how their performance is evaluated and which are their managers' decision rights—see Kaplan and Atkinson (1989); Jensen and Meckling (1998); and Brickley, Smith, and Zimmerman (2007), for example. While this theory was developed to study tradeoffs among different ways of organizing the production of private goods, we argue that it also provides a useful framework for understanding the organization of the public sector. This section provides a brief overview of the relevant ideas from the literature before we proceed to apply them in our empirical analysis.

\subsection{Classic bureaucracy as an expense center}

The Managerial Accounting literature denotes as a "discretionary expense center” (or “expense center”, for short) any department that receives a fixed budget that it uses to supply a service, often at no cost to users, who have no choice from which center to consume. The pay of expense center managers and employees is generally independent of the center's performance. The main rationale for this type of center is to respond to a 
situation in which output is subjective so that establishing performance benchmarks is impossible. When the organization designer cannot evaluate the cost of producing output or the value to users, a natural response is to eliminate all incentives. Typical examples of expense centers within business firms are human resource and public relations offices.

In the public sector, expense center organizations are quite common. For example, many countries have primary education systems that provide free schooling from a centralized budget. Children are assigned to schools on the basis of their residence, and teachers, who are paid with fixed salaries, de facto enjoy permanent employment as civil servants. This is an expense center insofar as there is no user choice, supplier incentives are weak to non-existent, and an education authority fixes the budget from above.

The main decision variable for controlling an expense center is the size of the budget. In what follows, we will refer to the "government" as the budget allocator, and consider as an expense center a particular government department. Of course, expense centers can themselves be part of larger expense centers, and the government as a whole might itself be considered such a center, as assumed by Niskanen (1968). We shall return to some of these complications in the case study below.

The absence of incentives in expense centers leads to predictable negative consequences. On the supply side, a natural assumption is that suppliers' objective is to maximize the budget size because of the power and prestige attached to receiving more funds; because their compensation is positively linked to the funds they receive; or because receiving more funds allows them to siphon some off for private consumption. Moreover, the absent link between pay and service quality means that the center will not undertake costly activities to improve quality. ${ }^{1}$ Moreover, if users pay no fees, they will demand the service until their marginal benefit is zero and not internalize production costs.

\footnotetext{
${ }^{1}$ Our characterization of expense centers is abstract, and we do not analyze potential mitigating forces. For example, it is also possible that bureaucrats have non-monetary incentives that lead them to provide quality, such as Weberian "public-spiritedness." Also, observability may be greater in the long term than in the short term, and incentive intensity adapted accordingly.
} 
The fact that suppliers and users both have a stake in large budgets combined with the government's lack of information about user preferences and supplier technology means that the most likely outcome of expense centers is overproduction of low-quality output. Indeed, this description fits well with the associations many people have with the very word bureaucracy.

Some public sector reforms maintain the expense center organization, and attempt to correct its distortions without changing incentives. One obvious way of dealing with bloated budgets is to reduce them through cuts, but this creates numerous practical problems. Given its lack of information, it is difficult for the government to identify which parts of the public sector generate the most waste. Rather than base budget cuts on any concrete measures of efficiency or performance, they are often applied across the board, eliminating both wasteful and valuable programs at the same time.

Even if governments did attempt to introduce differential budget cuts for departments on the basis of their inefficiency levels, such as in "zero-base" budgeting exercises, their judgments would be subjective and seriously constrained by information asymmetries. In this case, a main danger is that public sector managers engage in lobbying and other wasteful influence activities to persuade the government not to reduce the funds allocated to their respective divisions (Milgrom 1988). Suppliers can also use their informational advantage to manipulate budget cutting. When the government reduces the budget of a department, it can threaten to eliminate the services that consumers find the most valuable in order to maximize the indignation and reduce the probability of the cuts going through. For example, hospitals faced with budget cuts have emphasized the deaths that might result rather than focusing on reduction on non-clinical expenditures (Anthony and Young 1988).

Another reform strategy is for the government to improve its information by investing resources into collecting more of it. Additional information is valuable because when the government better knows the value that services create for users and the costs that suppliers incur to produce output, the better it is able to make efficient resource allocation decisions. As has long been recognized (Hayek 1945, Arrow 1964), though, there are clearly significant costs associated with acquiring information, especially in 
the public sector. ${ }^{2}$ Hence while governments usually do invest resources into additional information, they are generally unable to fully resolve the underlying problem this way. $^{3}$

We argue that the basic problem of bureaucracy relates to a lack of incentives, and that the only way to tackle the fundamental problem is to re-organize the centers to provide better incentives along some dimensions. At the same time, the government will in many cases want to restrict discretion on others. As we now describe, the literature provides several organizational forms that are alternatives to both expense centers and pure free markets.

\subsection{Alternative solutions to the problem of bureaucracy}

Table 1 lays out the main possibilities for alternative forms of organization besides the traditional expense center. Two broad points are important for our discussion. First, producing a good_-private or public_-involves many separate decisions: what inputs to use in production, how much to produce, to whom to sell output, at what prices, and so on. Each divisional unit in table 1 is characterized by a set of actions that it controls, and another set of actions that managers above the division control. This separation of tasks is what we mean by a "hybrid" organization. Second, the particular separation of tasks into a delegated set and a controlled set leads to predictably negative consequences if adequate incentives are lacking for the delegated set or adequate oversight for the controlled set. We now provide a more detailed discussion of each type of unit.

\footnotetext{
${ }^{2}$ This is not merely an academic concern. Recent attempts by the British National Health Service to collect patient information in an electronic database have been hit by long delays, billions of pounds of overspend, and criticisms over privacy (Beckett 2009). Moreover, once in place, the extent to which the information will be reliable and, even if reliable, will impact clinical outcomes, is unclear.

${ }^{3}$ Grossman and Helpman (2001) also discuss the possibility that governments can rely on interested third-party lobbyists to collect information that can help monitor agents. However, in many circumstances the interests of these third parties conflict with those of the government, limiting the extent to which they can be expected to truthfully disclose their local knowledge.
} 
Table 1: Alternative Organizations and Distribution of Decision Rights

\begin{tabular}{|c|c|c|c|c|}
\hline $\begin{array}{c}\text { Type of divisional } \\
\text { unit }\end{array}$ & $\begin{array}{l}\text { Performance } \\
\text { measure }\end{array}$ & $\begin{array}{l}\text { Delegated } \\
\text { actions }\end{array}$ & $\begin{array}{l}\text { Controlled } \\
\text { actions }\end{array}$ & $\begin{array}{l}\text { Typical } \\
\text { problems }\end{array}$ \\
\hline Cost center & Cost reduction & Input mix & Quantity, quality & Low quality \\
\hline Revenue center & Revenue increase & Sales activities & $\begin{array}{l}\text { Quantity, product } \\
\text { mix }\end{array}$ & Overselling \\
\hline Profit center & Accounting profit & Quantity, quality & $\begin{array}{l}\text { Transfer price, } \\
\text { investment }\end{array}$ & Monopoly pricing \\
\hline Investment center & ROE, ROA, EVA & $\begin{array}{l}\text { Quantity, quality, } \\
\text { investment }\end{array}$ & Ownership & $\begin{array}{l}\text { Poor investment } \\
\text { decisions }\end{array}$ \\
\hline Franchised unit & Economic profit & $\begin{array}{l}\text { Quantity, quality, } \\
\text { investment, } \\
\text { ownership }\end{array}$ & $\begin{array}{c}\text { Brand image, } \\
\text { entry }\end{array}$ & $\begin{array}{l}\text { Reputational } \\
\text { damage }\end{array}$ \\
\hline
\end{tabular}

Cost center managers are rewarded whenever they reduce the costs of producing a given output level. They have control over which inputs to use in production, but nothing else. As they earn more when costs are lower, they have a powerful incentive to seek out production efficiencies. As a result, two distortions can emerge. First, the production level associated with lowest unit costs (the minimizer of average cost) does not generally correspond to the efficient production level (at which marginal cost equals marginal benefit). Second, there will be an incentive to shirk on quality whenever this is costly to produce. So, those overseeing the cost center must be able to control and monitor both production levels and production quality.

A revenue center is the analog of a cost center for sales rather than production. It is rewarded when revenue increases. Again, the sales level that maximizes revenue (where marginal benefit is zero) does not correspond to the efficient level, and nearly always implies overselling. Also, revenue centers have an incentive to try to sell the most expensive items whenever there is more than one product. For these reasons, a revenue center is only effective when its sales level and product mix are controlled. Cost (revenue) centers can improve efficiency relative to an expense center when senior managers want a certain amount of well defined output produced (sold) but do not know 
the optimal production inputs (marketing techniques). At the same time, more junior employees may very well have this knowledge. If these employees were organized into an expense center, the senior managers would simply guess how much money production required and budget this for the center. Moreover, the expense center managers would attempt to exaggerate this figure. If the division instead had a cost center organization and were paid explicitly on the basis of budget underspent, it would have a clear incentive to produce the output as cheaply as possible. So long as senior managers were able to monitor quality and output levels, the transformation would be expected to improve efficiency. The key point is that a cost center's effectiveness results from a combination of incentives and control, not either one in isolation; put simply, hybridization is essential.

This basic example illustrates our key idea. The problem with expense center organizations in the public sector is that the government lacks knowledge about economically relevant variables. On the other hand, expense center employees (i.e. civil servants) in many cases have the information that the government lacks. In order to get these employees to act on their information and to use it to take efficient actions requires the provision of incentives. At the same time, incentive provision itself creates new opportunities for employees to game the system, for example by shirking on quality. Well-designed organizations must balance the need to provide incentives to induce employees to act on local information and the need to monitor and control activities to prevent them from taking exploitative actions.

When senior managers do not have precise knowledge of output and quality levels, cost and revenue centers are unlikely to operate efficiently. This will be the case when output is subjective and hard to measure, which as we pointed out above is one rationale for expense centers in the first place. To solve the problems of poor quality and overselling, senior managers can adopt alternative structures. For example, the performance of a profit center is measured in terms of net revenue, which at least partially induces employees to internalize the negative consequences of their actions on the bottom line. Here "profit" is computed in terms of an internal transfer price that may or may not correspond to a market price. The transformation or combination of cost and revenue centers into a profit center necessarily forces senior managers to determine appropriate prices. If pricing decisions are left to profit center managers, 
they have an incentive to act as a monopolist vis-à-vis other divisions that use their products - the classic double marginalization problem. While transfer pricing is a large and complex subject, we simply wish to point out that hybridization is again intrinsic to the successful operation of profit centers.

The remaining two types of hybrid divisions in Table 1 represent further delegation but still feature some senior managerial control. An investment center is allowed to raise and allocate capital, and evaluated on the basis of return on assets, return on equity or economic value added. Finally, a franchisee can control investment as well as sell assets to new entrants, and holds not mere decision rights, but also property rights, although the franchising organization usually restricts who is allowed to buy.

The boundaries between division types in Table 1 are necessarily imprecise, and we do not wish to suggest that an unambiguous classification always exists. Instead we view it as a useful tool that one can use to understand the benefits and costs of different kinds of bureaucratic organization. While developed for the study of multi-divisional private sector firms, we now elaborate case studies to illustrate its value for the analysis of public sector organizations.

\section{Case Study: Organizational Structure of Public Registries}

Public registries provide a fertile ground for applying our ideas on the organization of public services, as they are organized using a considerable variety of forms, as table 2 illustrates. Just as firms are composed of multiple, potentially heterogeneous divisions, so too can public registries have different types of structures at different levels. For our discussion, we separate out the organization of the government department charged with registering documents (typically run by senior civil servants or public sector managers) from the organization of the service providers: the registry offices themselves who actually provide registration services to the public. 
Table 2: Comparison of the institutional arrangements adopted at the two major levels of organization for the registries discussed in the case

\begin{tabular}{|c|c|c|c|c|c|}
\hline \multicolumn{2}{|c|}{} & $\begin{array}{c}\text { England HMLR } \\
\text { before the 1990 } \\
\text { reform }\end{array}$ & $\begin{array}{c}\text { US Patent and } \\
\text { Trademark } \\
\text { Office (PTO) }\end{array}$ & $\begin{array}{c}\text { England HMLR } \\
\text { after the 1990 } \\
\text { reform }\end{array}$ & $\begin{array}{c}\text { Spain's DGRN } \\
\text { and land } \\
\text { registries }\end{array}$ \\
\hline $\begin{array}{c}\text { Two major } \\
\text { organizational } \\
\text { layers between } \\
\text { government and } \\
\text { final users }\end{array}$ & $\begin{array}{c}\text { Government } \\
\text { department }\end{array}$ & $\begin{array}{c}\text { Expense } \\
\text { center } \\
\text { Service }\end{array}$ & $\begin{array}{c}\text { Revenue } \\
\text { center } \\
\text { providers }\end{array}$ & $\begin{array}{c}\text { Investment } \\
\text { center }\end{array}$ & $\begin{array}{c}\text { Expense } \\
\text { center }\end{array}$ \\
\hline \multicolumn{2}{|c|}{ centers } \\
Major problems & Waiting time & Low quality & $\begin{array}{c}\text { Cost } \\
\text { centers } \\
\text { low legal } \\
\text { quality }\end{array}$ & $\begin{array}{c}\text { Cost } \\
\text { centers } \\
\text { externalities }\end{array}$ & $\begin{array}{c}\text { Franchise } \\
\text { units }\end{array}$ \\
\hline
\end{tabular}

In all the registries we analyze, hybridization is a recurrent theme. The price charged to users is set centrally but the time dedicated by each registrar to make the registration decision is delegated, with registrars being motivated in different ways (from bonuses to profit). Other actions are set by each system depending on their particular form. For example, the hiring and use of resources is centrally controlled in those registries organized as expense centers while it is fully delegated and decided locally in franchised registries.

In the remainder of the case, we discuss how the problems of expense centers manifest themselves in registration before analyzing the various institutions described in table 2.

\subsection{Expense Centers}

As discussed in section 2, the typical problem of an expense center is the absence of incentives leading to low quality output. This problem can be seen in various registries across countries and time. Generally, expense centers show the poorest performance. For example, according to the World Bank’s Doing Business “Registering Property” index, the German land register or Grundbuch, which is organized as a standard expense center but for the fact that it is financed directly by user fees, charges 
substantially more (excluding taxes) that the Spanish and English registers while taking much longer to actually register documents. ${ }^{4}$ US land registries, which also are feefinanced expense centers, have for decades suffered low quality and substantial delay, leading to the development of private palliatives ranging from the "title plants" created by title insurance companies to the electronic registry of mortgage transfers (the Mortgage Electronic Registration Systems, known as MERS, which is at the core to the current foreclosure crisis) (Arruñada, 2012: 74-75, 113-14).

Variation within countries shows a similar pattern. The English land register prior to 1990 took more than 30 times longer to register documents than it does today, while the Spanish cadastre (a separate organization from the property register) generally takes between one and three years to process lodgments while the property register takes only about nine days. These differences do not appear to arise because of differences in the registration task. Spanish, English, and German property registries all register rights after examining the deeds; registering a document in England is much the same today as in 1990; and the task of the cadastre in Spain is significantly less complex than that of the property register.

Our hypothesis is that the variation in performance arises at least in part because of differences in organization. The Land Registry of England and Wales (HMLR) before 1990, along with the German property register and Spanish cadastre, are close to the bureaucratic expense center paradigm, while HMLR today and the Spanish property register are hybrid organizations that combine high-powered incentives on some dimensions and strict controls on others. At the same time, the way in which each does so is specific to local circumstances and causing particular undesirable side effects, as we describe below. The different organizations can be seen as-and in some cases, such as the English register have historically been-alternative responses to the typical failures of expense centers, responses that, in turn, are far from perfect and suffer serious and characteristic distortions.

\footnotetext{
${ }^{4}$ According to Doing Business 2014 (World Bank, 2013).
} 


\subsection{Cost and Revenue Centers}

The first types of hybrid organizations available for incentive provision are cost and revenue centers. Land registries have been in fact organized as cost centers in some titling efforts promoted by international aid agencies in developing countries. Given that these projects were subsidized, emphasis was often given to minimize the average cost of titling a massive number of land parcels or houses (Bruce et al., 2007, 42-43). As a consequence, the quality and value of titling are low, as indicated by the common observation that owners refuse to register subsequent transfers, even when they are still subsidized.

But for these extraordinary circumstances, driven by subsidization and the need of policymakers to show results fast, most land registries in developed countries have been organized with some attributes of revenue centers, charging a fee to users and financing their activities (and often much more) with such registration fees.

A main reason for this organization (which makes things very different from the healthcare case) is that registration is a complement to other, more valuable, transactions that users want to carry out, and these transactions do not significantly depend on the registration fee. Therefore, demand for registration is inelastic, which explains the charging of fees and the frequent use of registries as sources of taxation either directly, with fees well over registration costs, as in the Fantask case, pertinent at the time to several countries within the European Union (Arruñada, 2001) or indirectly, relying on them as gatekeepers of the payment of land transfer taxes (Kraakman, 1986). This emphasis on tax revenue is visible in the decision to create land and mortgage registries within the scope of the tax administration. Thus, $48.78 \%$ of the 41 registries surveyed by UN-ECE depends on ministries other than the Ministry of Justice of the courts (2000). On average, land registries that are branches of non-legal ministries provide lower quality services, as they are more likely to be mere registries of deeds instead of registries of rights. This means that registrars do archive the deeds and attest the date of their entry into the register (a date with important legal consequences) but do not check the legality of the transaction. As a consequence, transaction costs in future deals are usually greater. Reformers in the past were conscious that placing the registers within the realm of the courts or the Ministry of Justice (Germany, Spain) was 
well-suited to their primary goal of making the register a facilitator of private contracting (Arruñada, 2003).

The key point here, as discussed in the theory section, is that setting up efficient cost and revenue centers requires the government to monitor and control the quality of output. The professional nature of registration services makes this hard, especially when it involves a quasi-judicial element of legal review. The example of the US PTO, discussed next, provides a good illustration of this point.

\subsubsection{Quality distortions: the US Patent and Trademark Office}

All patent offices work on similar basis. After inventors apply for a patent, claiming that their idea provides a new, useful, and non-obvious solution for a given problem, examiners check these claims, granting the patent only if it meets those requirements and therefore does not collide with the state of the art or, as it is often known in patent law, the "prior art": that set of information that is publicly known when the patent is claimed and is thus pertinent to judge its originality. Most jurisdictions also contemplate a "patent opposition” process in which interested parties can bring information pertinent to the granting decision. If a patent is denied, applicants can often redraft their applications more narrowly.

The US PTO is theoretically organized along these lines, but its examination procedures have become increasingly weak. Despite the rhetoric about promoting innovation, the US Government has in fact succumbed to the lobbying efforts of the patent bar, interested in maximizing litigation, and the Treasury's interest in maximizing the office’s net revenue.

In our language, the system has been transformed from a conventional expense center into a revenue center. The PTO now maximizes revenue by granting patents as fast as possible, which increases gross revenue; and minimizes costs by granting patents with little review. This policy allegedly causes greater social cost in terms of additional 
litigation. ${ }^{5}$ The PTO's traditional mission has even been changed from “issue valid patents” to “help customers get patents” (Jaffe and Lerner 2004, 137). Consequently, examiners have been encouraged to process applications faster, often endangering examination quality. ${ }^{6}$ For example, the prior art considered is mostly the set of patents already granted, with little attention being paid to non-patented knowledge and practices. The risk of poor quality is compounded by the limitations for effective patent opposition by interested parties. The system has therefore been transformed into a de facto recordation system (which, in the intellectual property context, is confusingly called a "registration” system). Nevertheless, despite this weak examination and lack of opposition, a US patent still enjoys a presumption of validity, which is hard for alleged infringers to destroy in court because, among other reasons, they should provide "clear and reasonable evidence" proving that it is invalid.

Understandably, and contrary to often-claimed objectives of promoting innovation, this net revenue maximization strategy is costly in terms of insecure intellectual property, and exemplifies the large economic impact that poorly organized registries have in the economy. In particular, it has triggered an explosion of litigation, as the PTO grants numerous patents that interfere with prior art. Bessen and Meurer (2008, 130-45) estimate that firms spend 19 percent of their research and development budgets in defending patent lawsuits. And the system is unpredictable for all parties involved. Even district courts seem unable to predict the interpretation of the Federal Circuit court that sets most patent standards. For instance, the latter reverses the claim constructions of district courts in more than a third of cases (Moore 2005). And lawyers are equally unable to ascertain the scope and validity of patents. Their legal opinions, which cost between 20,000 and 100,000 USD, provide little assurance as to whether firms' technological choices protect them against infringement and are at best effective only to deny the willfulness of infringement. Overall, in many industries, it is impossible for

\footnotetext{
${ }^{5}$ The PTO thus provides another example of the ambiguity surrounding divisionalization units: it could be considered a revenue or a profit center depending on how strong the incentives on revenue generation and cost reduction are.

${ }^{6}$ See, for instance, a description of the incentives in the "Examiner Count System" in Hyra (2009) and United States Patent and Trademark Office (2009).
} 
innovators to find out whether they are infringing and to obtain clearance (Bessen and Meurer 2008).

The 2011 Leahy-Smith America Invents Act substantially reformed the US patent system; but, even if it is too soon to evaluate its long-term effects, the reform has kept the incentive structure described above mostly intact. In particular, it has additionally constrained "fee diversion" and enhanced the PTO’s ability to set fees, but this may at most only increase funding marginally. More importantly, the reform has not touched upon examiners' incentives (Lemley 2012) and, even if it has developed a post-grant opposition system, this is unlikely to be effective in improving the quality of patents or reducing litigation (Marshik 2013).

\subsection{Investment Centers and Her Majesty Land Registry (HMLR)}

Before 1990, HMLR was organized as a non-ministerial government department with no specific financial targets. In 1990, the British government converted it into a Trading Fund with an objective to return 3.5\% on average capital employed. The "return" is simply the total amount of user fees generated each year net of expenses, which HMLR keeps in a separate account at the Bank of England. ${ }^{7}$ Since HMLR controls neither prices (which are set by the government) nor demand (which depends on conditions in the property market), its financial objective basically gives its upperlevel managers strong incentives to find efficiency gains.

One of the main ways that HMLR can reduce costs is to capture economies of scale through the consolidation of offices. Indeed, the current number of offices in nearly half that in 1990 (14 instead of 26). Moreover, total employment has also fallen from 12,000 to roughly 5,000, and the long-run vision of HMLR is to use electronic registration for the majority of documents. There is little doubt that the drive to increase efficiency within HMLR in response to its financial target has been a primary factor in the reduction in registration times.

\footnotetext{
${ }^{7}$ Any surplus generated by HMLR remains in its account, which can be drawn down to cover losses in years with few property transactions.
} 
This arrangement has also led to substantial distortions. First, overall legal quality has suffered as a consequence of its emphasis on speedy registration and cost reduction. This also led to a costly effort in electronic registration that has mostly disappointed. Second, it is unclear if the system provides good incentives at the individual level. Although powerful incentives operate globally for HMLR, at an individual level they remain quite weak. Each of the 14 HMLR offices employs roughly 300 workers who are arranged hierarchically. The main control over workers' activity is direct supervision by workers at a higher rung. Nearly all workers receive a fixed salary, and the fraction of senior managers' pay made up by bonuses is on the order of $10 \%$. The liability from registration errors is covered by a state guarantee paid from HMLR's own account, and individual registrars face no personal liability.

\subsection{Franchising in the Spanish Land Register}

A drastic departure from the expense center model is that of the Spanish Land Register, whose organizational structure shares many features with that of private franchising networks even if its origins are very different. It was created in 1861 mixing elements of the Ancient Regime, in which public offices were sold to private investors and professionals (venality of offices), with the entry by public examination and regulation of procedures that are characteristic of the civil service introduced by the liberal state. As in private franchising, there is a central unit and a network of outlets. The central unit is a small government department (the Directorate General for Registers and Notarial Offices or DGRN) organized as a typical expense center. DGRN regulates the whole system, including decisions on entry (registrars are selected by public examination), the definition of detailed registration procedures, the closure and opening of registry offices, and, crucially, the fees that registries charge to users. The central unit also inspects and monitors how registries perform their duties, and decides on a first-instance and quasi-judicial capacity appeals against registration decisions. In addition to DGRN, registrars soon created a professional association that reaches economies of scale in many of their functions, including in later decades the development of national indexes and centralized information systems. 
While the DGRN is essentially a classic bureaucracy, individual registrars are subject to a set of strong incentives, including deferred and residual compensation, and personal liability. ${ }^{8}$ Registrars' compensation is deferred in time because, first, passing the entry exam requires significant investment in preparation and risk bearing. More importantly, vacant registry offices are periodically allocated on the basis of seniority, and, as offices differ in profitability, individual choices cause substantial deferred compensation. Each registrar manages a registry office, bears its costs and earns its residual profit. In particular, each registrar recruits the office's employees, who are not civil servants but are subject to standard labor law. Moreover, those employees with management responsibility are typically paid with a share of the office's profits. Lastly, Spanish registrars face strict personal liability for registration errors, which provides a strong incentive to avoid them. The risk that they may, as a consequence, be excessively cautious is counterbalanced by litigation by notaries in representation of contractual parties. The structure of fees also encourages speedy procedures, as registries are paid only after registration and their fees are reduced by 30\% when they take more than a set duration.

An interesting feature is the paucity of resources spent in the regulatory structure, which relies instead on contrary incentives at adjacent levels of the system. First, the few and selective civil servants responsible for the regulatory unit, the DGRN, were paid a fixed salary below that of both the registrars and notaries they were monitoring so they tended to be stern about any slackness. Moreover, their qualification was guaranteed by granting them the option to become a notary or registrar in a profitable office after a specific number of years working at the DGRN. (This option was much favored for the last few years of their careers and was similar to the pantoufles of senior French civil servants). Second, given that notaries are in competition for clients while registrars enjoy a territorial monopoly, they automatically tend to serve different interests and to control each other's work. Thus, while notaries are encouraged to serve their clients' interests, registrars are encouraged to reject registration of notary-mediated deeds that

\footnotetext{
${ }^{8}$ On the organization of Spanish registrars, see Nogueroles (2006). A similar hybrid organization - that of notaries public — is analyzed in Arruñada (1996).
} 
damage third-parties rights. In turn, notaries are encouraged to litigate registration refusals thus controlling possible registrars' tendency to be too strict.

These strong incentives encourage local efficiency in the use of variable resources (mainly labor) by each registry. These incentives are not so effective, however, in ensuring efficient capital investments or global efficiency at the level of the whole network. First, each registrar comes close to holding a property right on the office, as she is paid with the residual profit. However, registrars cannot sell their position. Therefore, their incentives to invest in the office are not optimal when they plan to hold it for a short-term period. For such a case, contractual arrangements between the two registrars successively holding the same office hardly provide the right incentives for local investment decisions. Second, as in any other franchising structure, each franchisee may be tempted to free ride on the whole network by lowering quality. Given the monopoly enjoyed by each registrar this resulted in the past in slow procedures (now corrected by the discounted fees) and still results in excessively heterogeneous decisions across the network, as each registrar enjoys full discretion to decide.

\subsection{Comparing English and Spanish Land Registries}

Thus both in England and in Spain, one finds both relatively productive organizations that combine bureaucratic controls and powerful incentives, albeit global in one and local in the other. On might argue this difference is an efficient response to the varied nature of registration in both countries. In Spain registers must record information about the contracts that define a transfer of property, but in England the contractual details are left out of the register. Moreover, England has a narrower number of property rights than Spain (in legal jargon, a stricter numerus clausus), so establishing the existence of conflicting rights is simpler in England than in Spain. To the extent that English registration is a standardizable, mechanical task one might argue that 
registrars need less discretion, which in turn implies less of a need for individual monetary incentives. ${ }^{9}$

Still, a reasonable conjecture is that the English register would benefit from more individual incentives to partially substitute the "direct control" of supervision with the “indirect control” of monetary incentives and thereby free up managers' time. Such incentives might also reduce registration errors, which some argue HMLR makes too often. Also in Spain there are several forces that encourage the proliferation of offices. First, registrars themselves benefit from more offices since it expands their career opportunities. Second, register users benefit from nearby offices. Finally, local politicians have a stake in keeping resources in their jurisdictions. The fact that no central authority bears the cost of keeping open Spain's roughly 1,000 offices (for only the 17 that keeps open the HMLR in the whole of England and Wales) makes it highly likely that there are unrealized economies of scale in the system. The larger point is that even within hybrid systems there are important tradeoffs to be resolved and the potential for inefficiencies to remain.

\section{Concluding remarks}

The Managerial Accounting literature has identified several types of division to balance the trade-offs among delegation, incentives, and control in private sector firms. We argue that this framework is also useful for identifying and addressing key problems in public good provision. First, the problems of bureaucracy are largely equivalent to those of a discretionary expense center. Second, alternative organizations can address the poor incentives present in such centers, but can create new incentive problems, such as an excessive focus on quantity at the expense of quality. The paper also illustrates

\footnotetext{
${ }^{9}$ Prendergast (2002) formalizes these ideas by showing that decentralization and strong monetary incentives are complementary instruments appropriate for environments in which there is a large amount of uncertainty about the "correct" action of the agent. Conversely, centralization and weak incentives are better suited to environments with highly predictable production processes.
} 
how several of these alternatives have been used in organizing public registries, and highlights their real-world costs and benefits.

More generally, the framework is helpful for understanding the impact of reform efforts in the public sector. For example, the World Bank’s Doing Business project addresses the problem of bureaucracy by focusing on the quantity of procedures users of public services must complete. Predictably, while this has indeed led to substantial administrative simplifications in many countries, it has also been criticized for misusing quantity indicators to the detriment of valuable service quality in the production of public goods (Arruñada 2007).

There are two broad areas for future contributions to build on these insights. First, the paper illustrates the complications of normative analysis by showing how different countries have adopted different solutions even for the provision of registration services, which are relatively simple compared to those that form a larger portion of government expenditure like education, health, and defense. For this reason, the paper does not provide a theory of optimal organization in the public sector. Such a theory would depend on numerous context-dependent factors and is beyond the scope of this paper. Second, the paper highlights that a deeper understanding of how close the analogy is between private and public sector organizations would be valuable. At first glance, one might imagine the primary difference is that the market provides more discipline for the private sector than the public. But to a large extent, exposure to market forces is itself a design variable. Both managers in the private and public sphere can determine whether users must consume in-house or can seek alternative providers in the market. 


\section{References}

Anthony, Robert and David Young. 1988. Management Control in Nonprofit Organizations, 4ed. Irwin: Homewood, IL.

Arrow, Kenneth J. 1964. “Control in Large Organizations.” Management Science 10(3): 397-408.

Arruñada, Benito. 1996. “The Economics of Notaries.” European Journal of Law and Economics 3:5-37.

Arruñada, Benito. 2001. "Mandatory Full-Cost Pricing in Public Services: How to Apply the 'Fantask' Sentence.” European Journal of Law and Economics 11(3):281-307.

Arruñada, Benito. 2003. "Property Enforcement as Organized Consent.” Journal of Law, Economics, and Organization 19(2):401-444.

Arruñada, Benito. 2007. "Pitfalls to Avoid when Measuring the Institutional Environment: Is ‘Doing Business’ Damaging Business?” Journal of Comparative Economics 35(4):729-747.

Arruñada, Benito. 2012. Institutional Foundations of Impersonal Exchange: The Theory and Policy of Contractual Registries, University of Chicago Press: Chicago.

Beckett, Andy. 2009. “System Failure?” The Guardian, 9 July.

Bessen, James, and Michael J. Meurer. 2008. Patent Failure: How Judges, Bureaucrats, and Lawyers Put Innovators at Risk. Princeton: Princeton University Press.

Brickley, James A., Clifford W. Smith, and Jerold Zimmerman. 2007. Organizational Architecture: A Managerial Economics Approach, 4ed. Irwin: Chicago.

Bruce, John W., Omar Garcia-Bolivar, Michael Roth, Anna Knox, and Jon Schmidt. 2007. "Land and Business Formalization for Legal Empowerment of the Poor." Strategic Overview Paper. United States Agency for International Development; Washington, DC.

Enthoven, Alain C. 1991. "Internal Market Reform of the British National Health Service.” Health Affairs 10(3):60-70.

Grossman, Gene M., and Elhanan Helpman. 2001. Special Interest Politics. MIT Press: Cambridge, MA.

Hayek, Friedrich A. 1945. “The Use of Knowledge in Society.” American Economic Review 35(4):519-530.

Hyra, Clifford D. 2009. "What Is the Examiners Motivation?,” January 12 (http://patents101.com/2009/01/what-is-the-examiners-motivation-part-2/print/, visited June 6, 2012). 
Jaffe, Adam B., and Josh Lerner. 2004. Innovation and Its Discontents: How Our Broken Patent System Is Endangering Innovation and Progress, and What To Do About It. Princeton: Princeton University Press.

Jensen, Michael C., and William H. Meckling. 1998. "Divisional Performance Measurement.” In M. C. Jensen, Foundations of Organizational Strategy, Harvard University Press: 345-361.

Kaplan, Robert S. and Anthony A. Atkinson. 1989. Advanced Management Accounting, 2ed. Prentice-Hall: Englewood Cliffs, NJ.

Kraakman, Reinier H. 1986. "Gatekeepers: The Anatomy of a Third-Party Enforcement Strategy.” Journal of Law, Economics, and Organization 2(1):53105.

Lemley, Mark A. 2012. "Fixing the Patent Office.” National Bureau of Economic Research Working Paper Series 18081.

Marsnik, Susan. 2013. "Will the America Invents Act Post-Grant Review Improve the Quality of Patents? A Comparison with the European Patent Office Opposition.” In D. R. Cahoy and L. J. Oswald, eds., The Changing Face of American Patent Law and its Impact on Business. Edward Elgar Publishing Ltd.: Cheltenham.

Milgrom, Paul R. 1988. "Employment Contracts, Influence Activities, and Efficient Organization Design.” Journal of Political Economy 96(1):42-60.

Moore, Kimberly A. 2005. “Markman Eight Years Later: Is Claim Construction More Predictable?” Lewis and Clark Law Review, 9(1):231-247.

Niskanen, William. 1968. "Nonmarket Decision Making: The Peculiar Economics of Bureaucracy.” American Economic Review 58(1):293-305.

Nogueroles, Nicolás. 2006. “El registrador.” In Luis María Díez-Picazo, ed., El oficio de jurista, 183-218. Madrid: Siglo XXI.

Prendergast, Canice. 2002. “The Tenuous Trade-off between Risk and Incentives,” Journal of Political Economy, 110(5): 1071-1102.

UN-ECE (United Nations Economic Commission for Europe). 2000. Study on Key Aspects of Land Registration and Cadastral Legislation. Her Majesty’s Land Register: London.

United States Patent and Trademark Office, 2009, “Joint Labor and Management Count System Task Force Proposal.” Update to the Examining Corps, September 30. United States Patent and Trademark Office and Patent Office Professional Association: Washington DC (http://www.uspto.gov/web/offices/ac/ahrpa/opa/documents/briefing_for_corpsfinal_draft-093009-external-jrb.pdf, visited June 6, 2012).

World Bank. 2013. Doing Business 2014: Understanding Regulations for Small and Medium-Size Enterprises. World Bank: Washington, DC. 